\title{
Biodegradation of Brown 706 Dye by Bacterial Strain Pseudomonas aeruginosa
}

\author{
Asad Ullah Khan ${ }^{1}$, Mujaddad Ur Rehman ${ }^{1}$, Muhammad Zahoor ${ }^{2, *} \mathbb{D}$, Abdul Bari Shah ${ }^{3} \mathbb{D}$ and Ivar Zekker ${ }^{4, *}$ \\ 1 Department of Microbiology, Abbottabad University of Science and Technology, Havelian 22010, Pakistan; \\ asad.microbiology@gmail.com (A.U.K.); mujaddad@aust.edu.pk (M.U.R.) \\ 2 Department of Biochemistry, University of Malakand, Chakdara Dir Lower 18800, Pakistan \\ 3 Division of Applied Life Science (BK21 Plus), IALS, Gyeongsang National University, Jinju 52828, Korea; \\ abs.uom28@gmail.com \\ 4 Institute of Chemistry, University of Tartu, 14a Ravila St., 50411 Tartu, Estonia \\ * Correspondence: mohammadzahoorus@yahoo.com (M.Z.); ivar.zekker@ut.ee (I.Z.)
}

Citation: Khan, A.U.; Rehman, M.U.; Zahoor, M.; Shah, A.B.; Zekker, I. Biodegradation of Brown 706 Dye by Bacterial Strain Pseudomonas aeruginosa. Water 2021, 13, 2959. https://doi.org/10.3390/ w13212959

Academic Editor: Chao Yang

Received: 9 October 2021

Accepted: 18 October 2021

Published: 20 October 2021

Publisher's Note: MDPI stays neutral with regard to jurisdictional claims in published maps and institutional affiliations.

Copyright: () 2021 by the authors. Licensee MDPI, Basel, Switzerland. This article is an open access article distributed under the terms and conditions of the Creative Commons Attribution (CC BY) license (https:// creativecommons.org/licenses/by/ $4.0 /)$.

\begin{abstract}
Dyes are the most challenging pollutants for the aquatic environment that are not only toxic, but also interfering photosynthesis as light penetration into deep water is changed. A number of methods are used for the water reclamation, however, among them biological methods are preferably used due to their compatibility with nature. In the present research, 15 different bacterial strains were used to decolorize Brown 706 dye. Among the bacterial strains, Pseudomonas aeruginosa showed maximum decolorization activity; hence in the subsequent experiments Pseudomonas aeruginosa was used. First the decolorization activities were carried out under different physicochemical conditions to obtain the optimum decolorization benefits of the selected microorganism. The optimum conditions established were $37^{\circ} \mathrm{C}$, $\mathrm{pH}$ of 7 and operation cycle time $72 \mathrm{~h}$. In the subsequent experiment all optimum conditions were combined in a single experiment where $73.91 \%$ of decolorization efficiency was achieved. For the evaluation of metabolites formed after decolorization/degradation the aliquots containing bacteria were homogenized, filtered and then subjected to extraction. The extracted metabolites were then subjected to the silica gel column isolation. UV-Vis, FTIR, and NMR techniques were used to elucidate structures of the metabolites. Out of the collected metabolites only P-xylene was identified, which has been formed by cleavage of azo linkage by azo reductase enzyme of bacteria following the deamination and methylation of nitro substituted benzene ring.
\end{abstract}

Keywords: biodegradation; Brown 706 dye; Pseudomonas aeruginosa; textile wastewater

\section{Introduction}

The growing population needs has resulted in the advancement of the new technologies which have caused the environmental balance disturbance throughout the world, observable in the form of water, soil, and atmospheric pollution [1]. Water is essential for the existence of life; therefore, the quality of water is the most important aspect to be monitored everywhere on the globe to ensure healthy lives of the human population [2]. Water pollution directly affects human activities and health [3]. Unfortunately, waste materials are directly discharged into water causing water pollution in many countries around the world [4]. Water pollutants include heavy metals, organic compounds including dyes and other synthetic compounds, and inorganic compounds [5]. A basic criterion for drinking water is to be colorless and odorless, which unfortunately is not fulfilled in many regions of the world [6,7]. Such waters are considered polluted as they have altered quality or composition. These alterations are sometime natural while in other cases they may be anthropogenic [3]. The dyes-contaminated water cannot be used for domestic purposes [8].

The dyes-loaded water causes some diseases in human beings, like skin dermatitis, allergies, etc. [9]. Additionally, colored water negatively affects the photosynthesis of aquatic plants leading to suffocation of aquatic organisms in deep water $[10,11]$. A number 
of attempts have been made to decolorize or degrade the dyes [12]. Broadly, these methods are classified as physical, chemical and biological methods. The chemical and physical methods are expensive and are also associated with formation of secondary sludge which is hard to dispose up. Biological methods have advantages over other methods as they are environmentally friendly and cost-effective [13]. Bacteria being a dweller of varied environments and conditions is preferably used for such purposes. Additionally, its multiplication power and growth are high that is why it has been used previously for the degradation/decolorization of dyes. However, there are limited studies where researchers have studied nature of resulting metabolites of degradation. There is a dire need to determine the nature of metabolites of dyes as sometime the metabolites formed are more toxic than the original dye and in that case such type of transformations are worthy of nothing [1,2]. Brown 706 is extensively used in coloring of lather, cloth etc. has not been subject to such type of studies before.

In recent years, the unprecedented development of industrial and urban activities has led to a significant increase in wastewater discharge into the environment, often polluted with harmful organic contaminants. Thus, the separation/elimination of these contaminants from water bodies is a goal that must be accomplished to ensure human and environmental safety. The importance of the nature of the degradation products by microbes has not been investigated adequately before, therefore, the purpose of this research project was to investigate the efficacy of various bacterial strains in the breakdown and decolorization of the dye. Brown 706 and the Pseudomonas aeruginosa bacteria showed high efficacy for the degradation of the selected dye as compared to other bacterial strains. The effect of various physicochemical parameters on dye degradation was also evaluated in order to get optimum conditions of adsorption. To obtain an insight into metabolites formed after degradation, the extracted isolates were purified through column chromatography while for structural elucidation different spectroscopic techniques were used.

\section{Material and Methods}

\subsection{Experimental}

The Brown 706 and all of the necessary chemicals, including nutrient broth, sodium hydroxide, sugar, sodium chloride, hydrochloric acid and sodium chloride, were of the highest quality (analytical grade) and were used without further purification (purchased from Sigma Aldrich, Germany).

Brown 706 molecular formula is $\mathrm{C}_{12} \mathrm{H}_{14} \mathrm{~N}_{6} \mathrm{O}_{9} \mathrm{SNaFe}$ with molecular weight; $483.167 \mathrm{~g} / \mathrm{mol}$. Its chemical structure is given below in Figure 1 .<smiles>Nc1cc2n(c1)N(c1ccc([N+](=O)[O-])cc1)C(OP(O)(O)(O)O)=CC([N+](=O)[O-])=C2</smiles>

Figure 1. Chemical Structure of Brown 706 dye.

Fresh biomass of the 15 different bacterial strains grown in nutrient broth were used for the decolorization of Brown 706 dye as per the given detail in Figure 2. The experimental conditions were; $20 \mathrm{ppm}$ dye, $37^{\circ} \mathrm{C}, 15 \mathrm{~mL}$ broth media mixed with bacterial inoculum taken from bacterial suspension of $10^{8}-10^{9} \mathrm{CFU} / \mathrm{mL}$, incubated for 3 days at neutral $\mathrm{pH}$. 


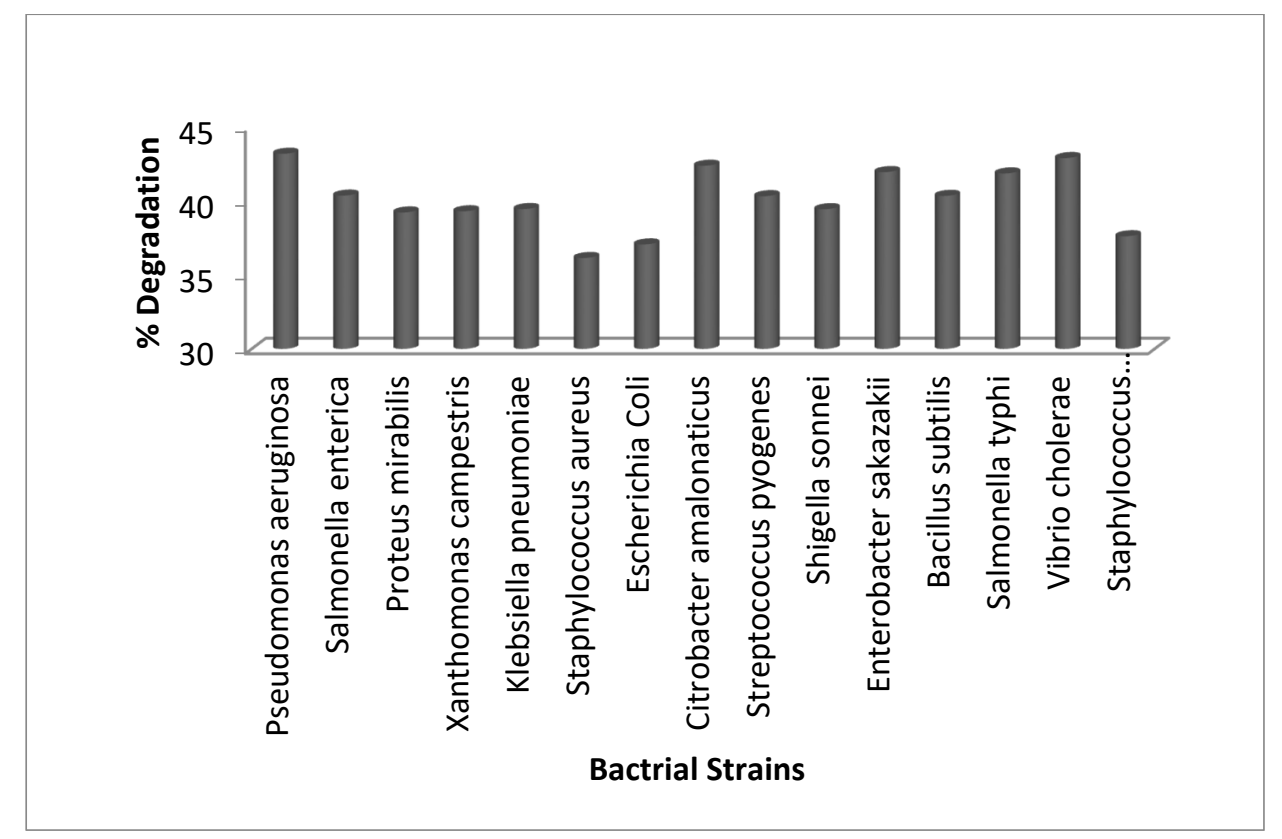

Figure 2. Percent degradation of selected dye different bacterial strains ( $20 \mathrm{ppm}$ concentration, $37^{\circ} \mathrm{C}, 15 \mathrm{~mL}$ broth medial mixed with bacterial inoculum taken from bacterial suspension of $10^{8}-10^{9} \mathrm{CFU} / \mathrm{mL}$, incubated for 3 days at neutral $\mathrm{pH}$ ).

The decolorization of the dye were carried out in test tubes having a capacity of $20 \mathrm{~mL}$ containing $15 \mathrm{~mL}$ of nutrient broth and dye solution. The nutrient broth containing Brown 706 was autoclaved at $121^{\circ} \mathrm{C}$ for $15 \mathrm{~min}$ to avoid contamination by unwanted bacteria. The cultures of each bacterial strain were added to different test tubes having sterilized nutrient broth medium, and Brown 706 and incubated at $37^{\circ} \mathrm{C}$ in an incubator for 3 days. The culture media was then withdrawn by pipette into centrifuge tubes. To separate the supernatant and pellet, the tubes were centrifuged at $5000 \mathrm{rpm}$ at room temperature for $20 \mathrm{~min}$. The extent of degradation in the supernatant was estimated through UV-Visible spectrophotometric analysis.

The following formula was used to estimate the degradation capabilities of the selected bacterial strain [14].

$$
\% \text { Decolorization }=\frac{\text { Initial absorbance }- \text { final absorbance }}{\text { Initial absorbance }} \times 100 \%
$$

Among the used strains Pseudomonas aeruginosa was the most efficient strain to decolorize the selected dye therefore, it was was in subsequent decolorization studies.

\subsection{Optimization of the Physicochemical Parameters for the Optimum Dye Degradation 2.2.1. Effects of Dye Concentration on Dye Degradability}

To study the effect of dye concentration on dye degradation under the applied conditions, Pseudomonas aeruginosa was cultured for 3 days in five different concentrations. Each test tube contains $15 \mathrm{~mL}$ of the nutrient broth and different concentrations of the selected dye (100, 80, 60, 40 and $20 \mathrm{ppm})$. After 3 days of incubation the culture tubes mixture was centrifuged at $5000 \mathrm{rpm}$ for $20 \mathrm{~min}$ and the remaining concentration of dye in supernatant was determined through UV-Visible spectrophotometer at $467 \mathrm{~nm}$ [15].

\subsubsection{The Impact of $\mathrm{pH}$ on Dye Degradation}

To study the effect of $\mathrm{pH}$ on Brown 706, 13 culture tubes having nutrient broth and selected dye $(20 \mathrm{ppm})$ at different $\mathrm{pH}$ ranging from 1 to 13 were inoculated with Pseudomonas aeruginosa and incubated at $37^{\circ} \mathrm{C}$ for three days as mentioned before. For the adjustment of $\mathrm{pH}$ values, $1 \mathrm{~N} \mathrm{HCl}$ and $1 \mathrm{~N} \mathrm{NaOH}$ were used. The $\mathrm{pH}$ was adjusted before inoculation as adding acid or base could harm bacteria on surface of mixture. 
The samples of culture tubes were centrifuged at $5000 \mathrm{rpm}$ for $20 \mathrm{~min}$. The remaining concentration in the aliquots were determined through UV-Visible spectrophotometer [16].

\subsubsection{Effect of Temperature on Dye degradation}

About 20 ppm solutions of Brown 706 in nutrient broth were incubated at 15, 25, 37 and $45^{\circ} \mathrm{C}$. After 3 days of incubation the remaining concentration in culture tubes were determined through UV-Visible spectrophotometer following the procedure as mentioned above.

\subsubsection{Glucose Concentration and Its Effect on Dye Degradation}

The nutrient broth tubes containing $20 \mathrm{ppm}$ dye were supplemented with $0.1,0.2,0.3$, $0.4,0.5,06,07$ and $0.8 \mathrm{~g}$ of glucose as extra carbon source incubated at $37^{\circ} \mathrm{C}$. The remaining dye concentrations after 3 days of incubation were determined as mentioned above.

\subsection{5. $\mathrm{NaCl}$ Concentration Effect on Dye Degradation}

Sodium chloride is a major component in sea water; therefore, it will affect the efficiency of bacterial to degrade a given pollutant. About 7 tubes prepared by the mentioned procedure were supplemented with $0.1,0.2,0.3,0.4,0.5,0.6$ and $0.7 \mathrm{~g}$, were incubated at $37^{\circ} \mathrm{C}$ for 3 days and then Equation (1) was used to determine the remaining concentration in supernatant.

\subsubsection{Effect of Time on Dye Degradation}

A number of tubes containing $20 \mathrm{ppm}$ of brown 706 in nutrient broth were incubated for 7 days. After $24 \mathrm{~h}$ samples were taken, centrifuged at $5000 \mathrm{rpm}$ and concentration of the remaining dye was estimated from UV-Visible absorbance at $467 \mathrm{~nm}$.

\subsection{Degradation of Selected Dye under Optimal Conditions}

The optimal conditions (optimal $\mathrm{pH}$, dye concentration, temperature, time, glucose concentration and sodium chloride concentration) established in the above experiments were combined in a single experiment in order to check their synergistic effect and achieve maximum degradation. The rest of the experimental condition were the same as mentioned above.

\subsection{Extraction, Isolation and Identification of Metabolites of Degradation}

Pseudomonas aeruginosa degraded culture under optimum conditions were crushed and centrifuged at $5000 \mathrm{rpm}$ for $20 \mathrm{~min}$ at room temperature. To extract the metabolites from the cell free culture, the supernatant was used which was then treated an equal quantity of ethyl acetate and vigorously shaken for $25 \mathrm{~min}$. To obtain a solid extract, the ethyl acetate was evaporated at $40^{\circ} \mathrm{C}$. A part of the extract obtained was subjected to GC-MS analysis while other part was subjected to column isolation for purification. The minute quantity of the extract was then mixed with silica gel (70-230 mesh) to form slurry, which was then air-dried to remove any solvent. A column with a diameter of $4 \mathrm{~cm}$ and a height of $75 \mathrm{~cm}$ was packed with silica gel up to a height of $40 \mathrm{~cm}$ and washed with $500 \mathrm{~mL}$ of n-hexane. The crude extract slurry was then loaded carefully to the top of the column, which was then washed with n-hexane, and followed by elution with various ratios of ethyl acetate to $n$-hexane $\{1: 5,1: 2,1: 1,2: 1,5: 1\}$ solvent system. The effluents from column were collected in glass vials. Based on TLC profiling similar fractions were combined and re-chromatogrammed. For elution, $75 \mathrm{~mL}$ of each solvent were used, and we collected $5 \mathrm{~mL}$ fractions. Thin-layer chromatography was used to confirm the metabolites. The purified fraction was then subjected to spectroscopic analysis.

\subsubsection{GC-MS Analysis of Crude Extract}

An Agilent USB-393752 gas chromatograph (Agilent Technologies, Palo Alto, CA, USA) with HHP-5MS 5\% phenyl methyl siloxane capillary column $(30 \mathrm{~m} \times 0.25 \mathrm{~mm} \times 0.25 \mu \mathrm{m}$ film thickness; Restek, Bellefonte, PA, USA) equipped with an FID detector for the identi- 
fication of metabolites was used. First, the oven temperature was maintained at $70^{\circ} \mathrm{C}$ for $1 \mathrm{~min}$, then raised to $180^{\circ} \mathrm{C}$ within $5 \mathrm{~min}$. Finally, the temperature was raised to $280^{\circ} \mathrm{C}$ for $20 \mathrm{~min}$. The injector temperature was $220^{\circ} \mathrm{C}$ while that of the detector was $290^{\circ} \mathrm{C}$. The carrier gas was helium (flow rate of $1 \mathrm{~mL} / \mathrm{min}$ ). About $1 \mu \mathrm{L}$ sample was injected manually in a split-less mode.

GC/MS analysis of the metabolites was carried using the above-mentioned system however, this time coupled with an Agilent HP-5973 (Ramsey, Minneapolis, USA) mass selective detector in the electron impact mode (ionization energy: $70 \mathrm{eV}$ ) operated under the same conditions as described for GC.

The metabolites were identified through comparison of their retention times with the retention times of the authentic compounds reported in the literature (Wiley and NIST libraries).

\subsubsection{FTIR and H-NMR Analysis of the Metabolites}

Perkin Elmer Spectrum Two instrument (103385; Waltham, MA, USA) was used to get FTIR spectra of dye before and after degradation. The metabolites after purification through silica gel column were then subjected to NMR analysis as well.

\section{Results and Discussion}

\subsection{Highly Potent Bacterial Strain}

Different bacteria strains showed different removal percentages for decolorization. Out of 15 bacterial strains, Pseudomonas aeruginosa was found to be the most efficient bacterial strain. It reached $45 \%$ degradation of the dye. The overall degradation capabilities of all used strains are shown in Figure 2.

\subsection{Effect of Dye Concentration on Degradation}

The effect of dye concentration on dye degradation is given in Figure 3. The highest degradation potential was recorded for $20 \mathrm{ppm}$ solution. It shows that high concentration of the selected dye is toxic for the selected bacterial strain. Therefore, low concentration of dye should preferably be used while studying the dyes degradation by bacteria. Saratale et al. [17] reported that increase in the dye concentration resulting in a reduction in the percentage of dye degradation. The dye and the resulting metabolites have a toxic effect on bacterial cell growth. Additionally, it is possible that the dye molecules are interfering with the active sites of the azoreductase enzyme, resulting in decreased efficiencies of the selected dyes under study. Thus, high degradation performance by microbes can be recorded for lower concentrations rather than higher one.

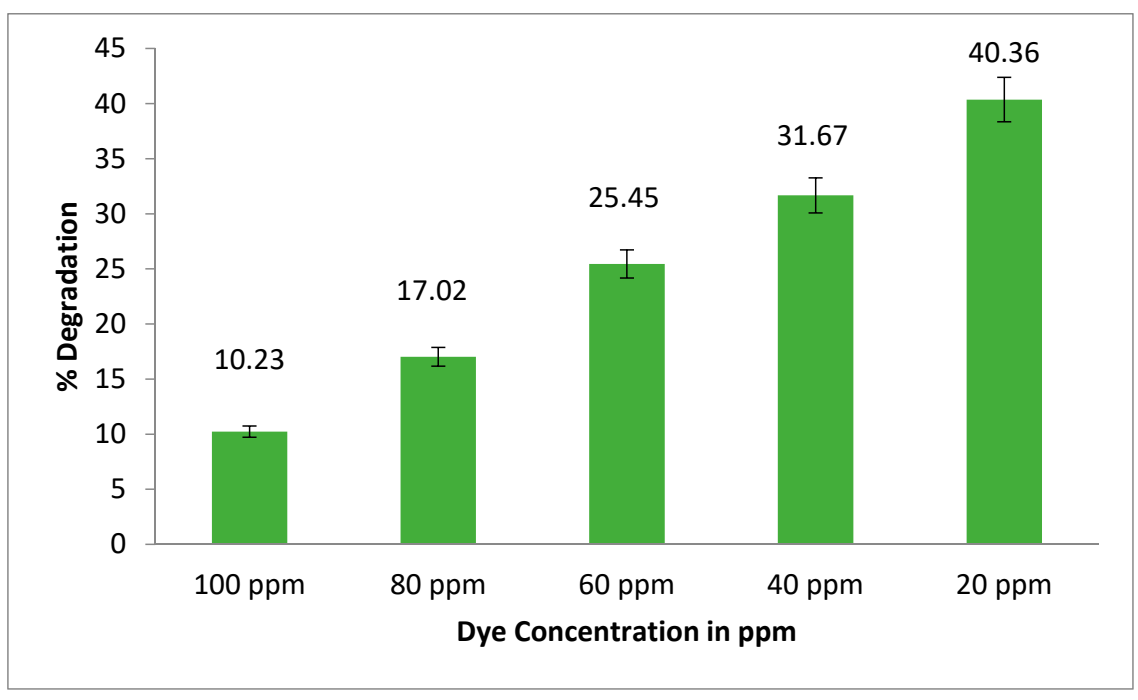

Figure 3. Dye concentration effect on the \% degradation of brown 706. 


\subsection{Effect of $p H$}

The effect of $\mathrm{pH}$ on the selected dye degradtion is shown in Figure 4 where highest capability can be observed at neutral $\mathrm{pH}$. On both side of this neutral $\mathrm{pH}$ there is a decline in biodegradation capability of the selected bacterial strain. Our results are in close agreement with a previousely reported study where highest biodegradation have been observed at neutral $\mathrm{pH}$ [18]. Sunar et al. [19] reported that the highest bacterial dye degradation can be achieved at neutral $\mathrm{pH} 7$ (in his study degradation of selected dye was $70.80 \%$ ). As the $\mathrm{pH}$ increases or decreases from the neutral range, bacterial division and enzymatic activity decreases.

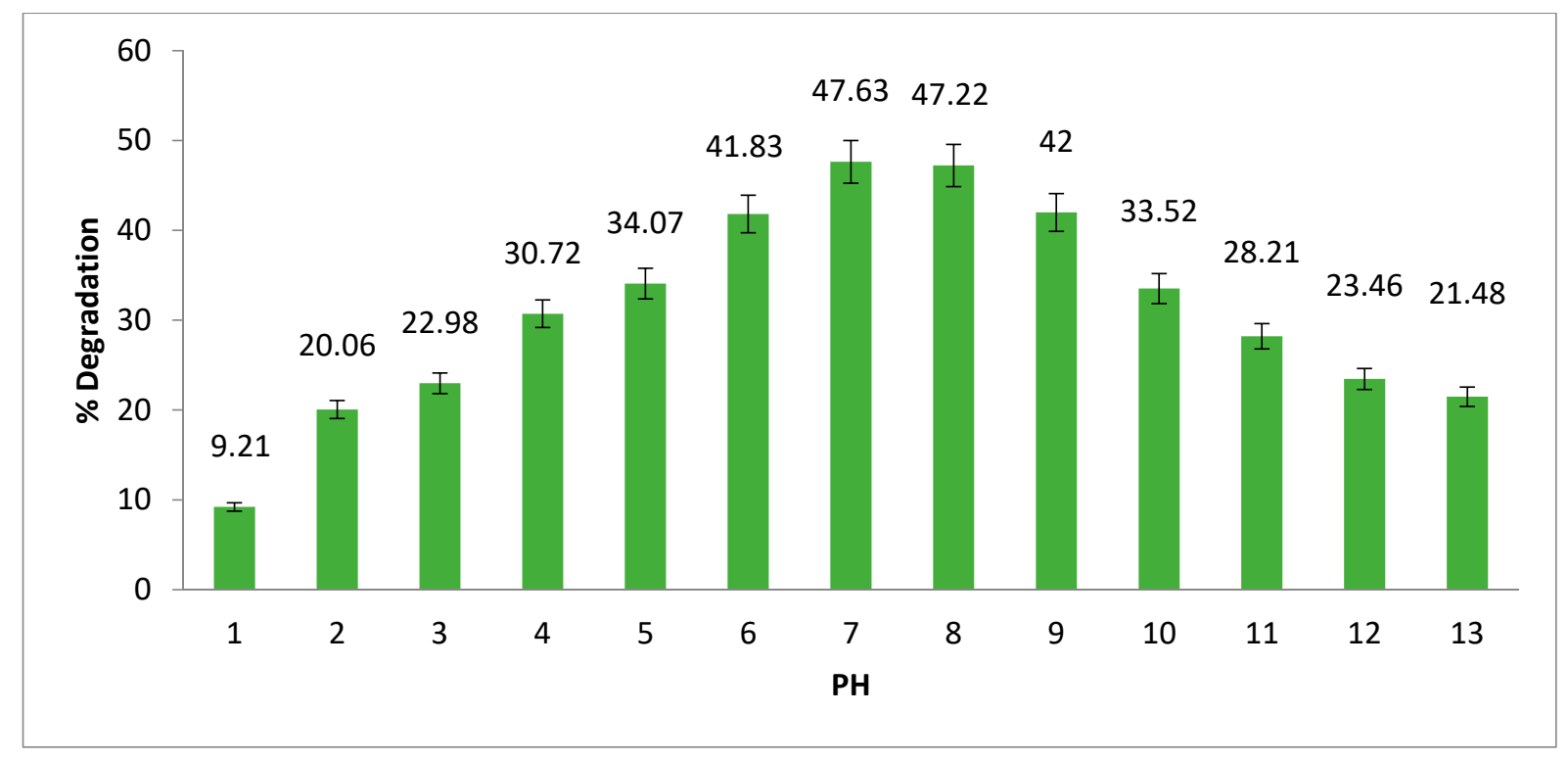

Figure 4. Effect of $\mathrm{pH}$ on \% degradation of brown 706.

\subsection{Effect of Temperature}

The effect of temperature on bacterial growth and consequently upon degradation is shown in Figure 5. The optimum degradation capacity of $40.75 \%$ was observed for temperature $37^{\circ} \mathrm{C}$. Below and above this temperature the degradation potential gradually decreased as the bacterial growth slowed down. According to Pearce et al., temperatures between 35 and $45^{\circ} \mathrm{C}$ are ideal while performing bacterial degradation experiments. Above and below, these limits the rate of azo dye degradation decreases. High temperature effects the bacterial cell division and denaturation of the azoreductase enzyme is encountered. The decrease in temperature also decreases bacterial growth [20].

\subsection{Effect of Glucose Supplementation on Dye Degradation}

Glucose serves as a carbon source for bacteria, which helps in enhancing the breakdown of dye through the formation of increased biomass. As some dyes are complex and cannot be easily biodegraded, additional carbon sources such as glucose are required as a carbon supplement [21]. The effect of glucose supplementation on the selected dye degradation is shown in Figure 6. Glucose supplementation of $0.5 \mathrm{~g}$ per $15 \mathrm{~mL}$ has resulted in high degradation of the selected dye. The decreased degradation activity at high glucose supplementation is due to its negative effect on bacterial metabolism known as sugar catabolic repression [22]. 


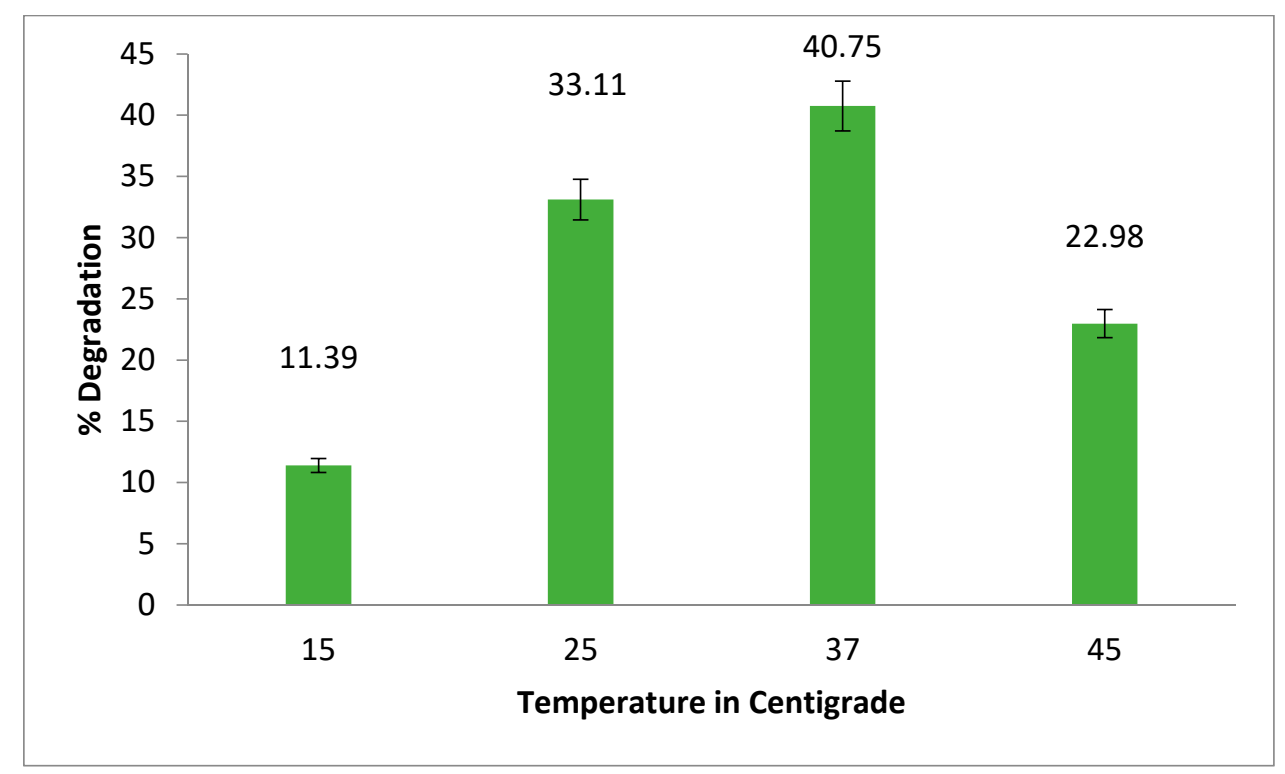

Figure 5. Temperature effect on \% degradation of brown 706 .

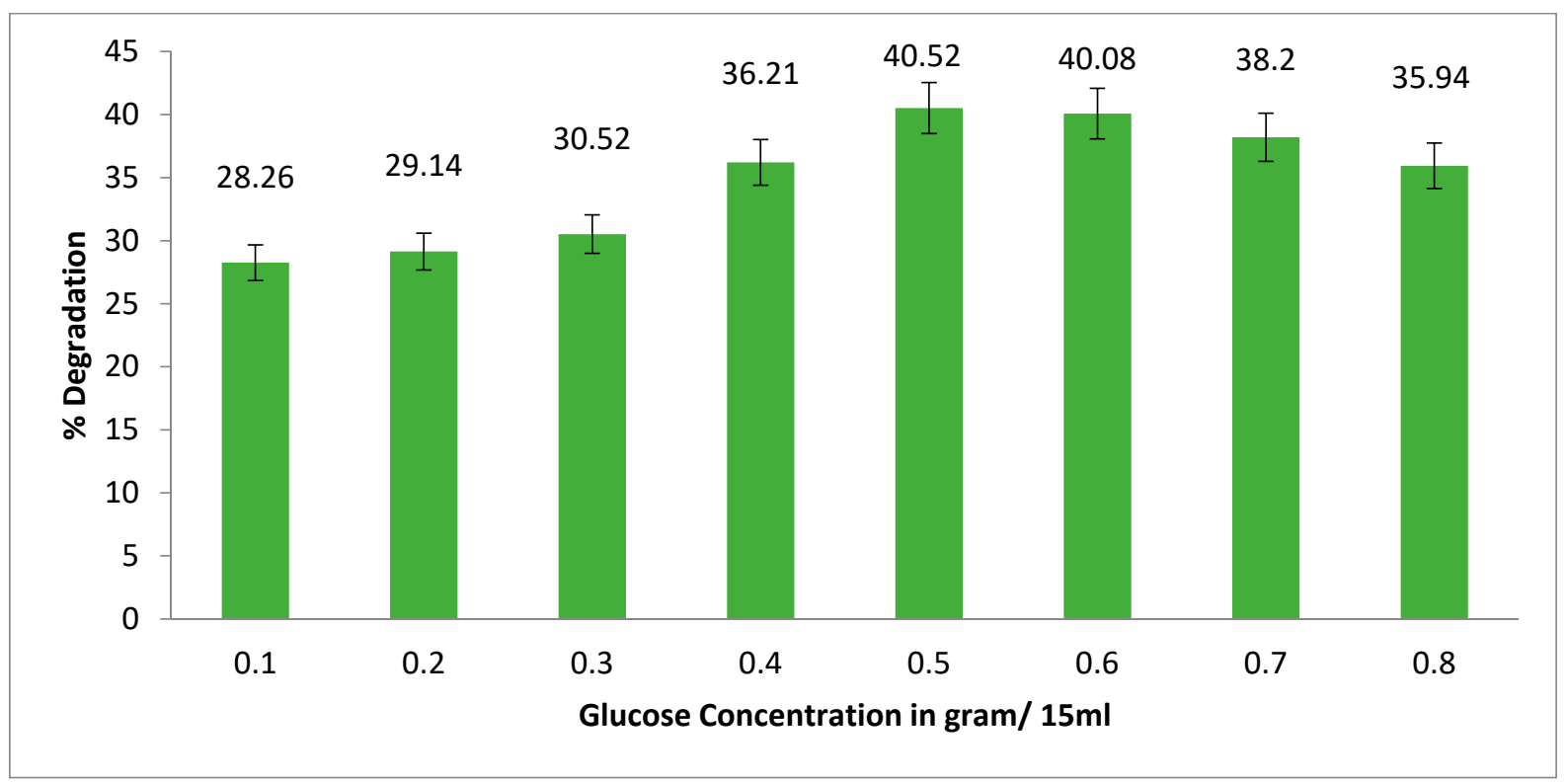

Figure 6. Glucose concentration effect on \% degradation of brown 706.

\subsection{The Effect of the Concentration of Sodium Chloride on Dye Degradation}

As we know that the industrial effluent contains high concentration of salts, we have therefore tested the microorganism degradation capability of the selected dye in the presence of varied salt concentration [23] where $0.1 \mathrm{~g} \mathrm{NaCl}$ supplementation have been found to be the optimum salt concentration (Figure 7). High concentration of salt causes plasmolysis of bacteria cell leading to reduce growth of bacteria, and as a result, degradation of dye decreases [24]. 


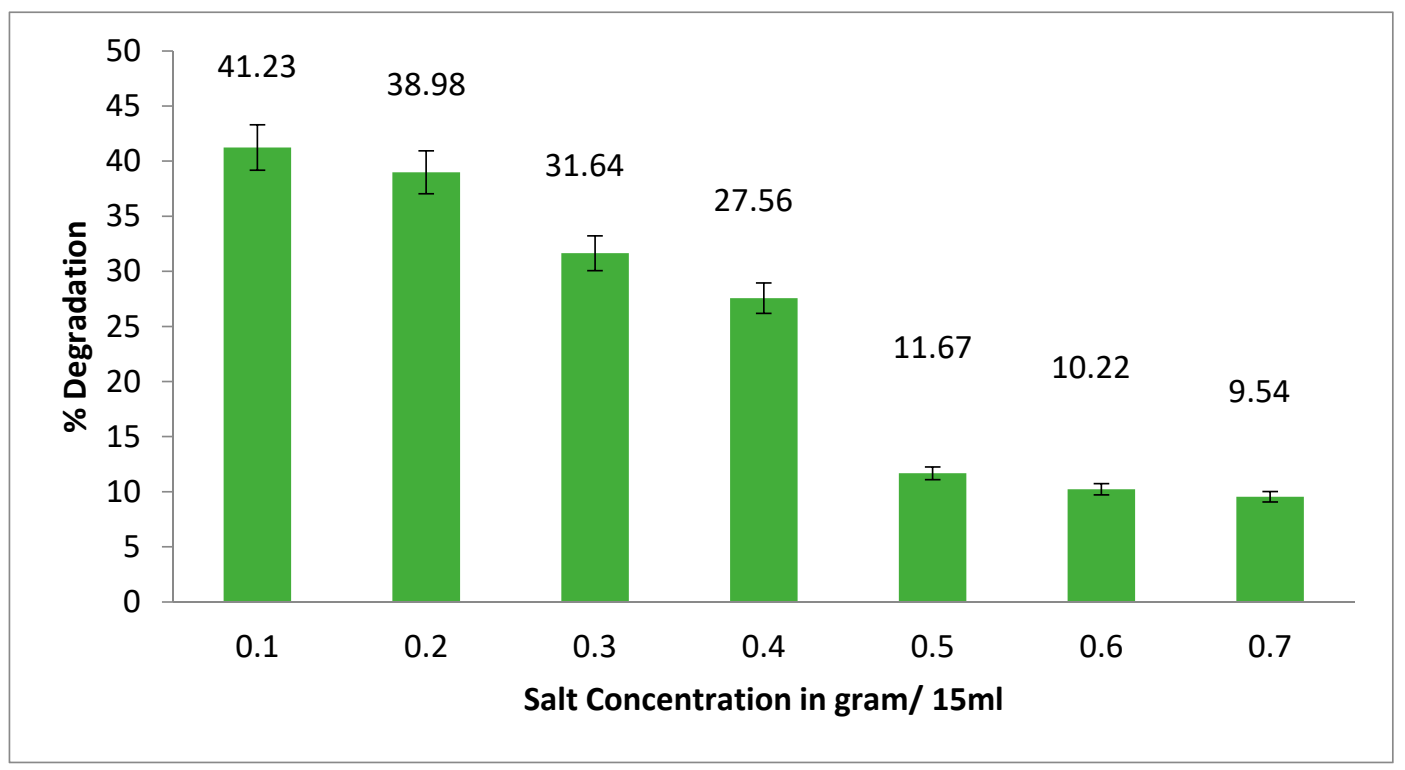

Figure 7. Salt concentration on \% degradation of brown 706.

\subsection{The Effects of Time}

The influence of time s on degradation of brown 706 by Pseudomonas aeruginosa is shown in Figure 8. There is an increase in degradation with time. However, after 3 days the increase is not so drastic, therefore, 3 days incubation has been taken as the optimum time. The degradation of dye initially increases with an increase in incubation period as biomass production increases, but later on there is a competition for nutrients in the media. Therefore, the increase in biomass and consequently degradation after the third day is not so significant.

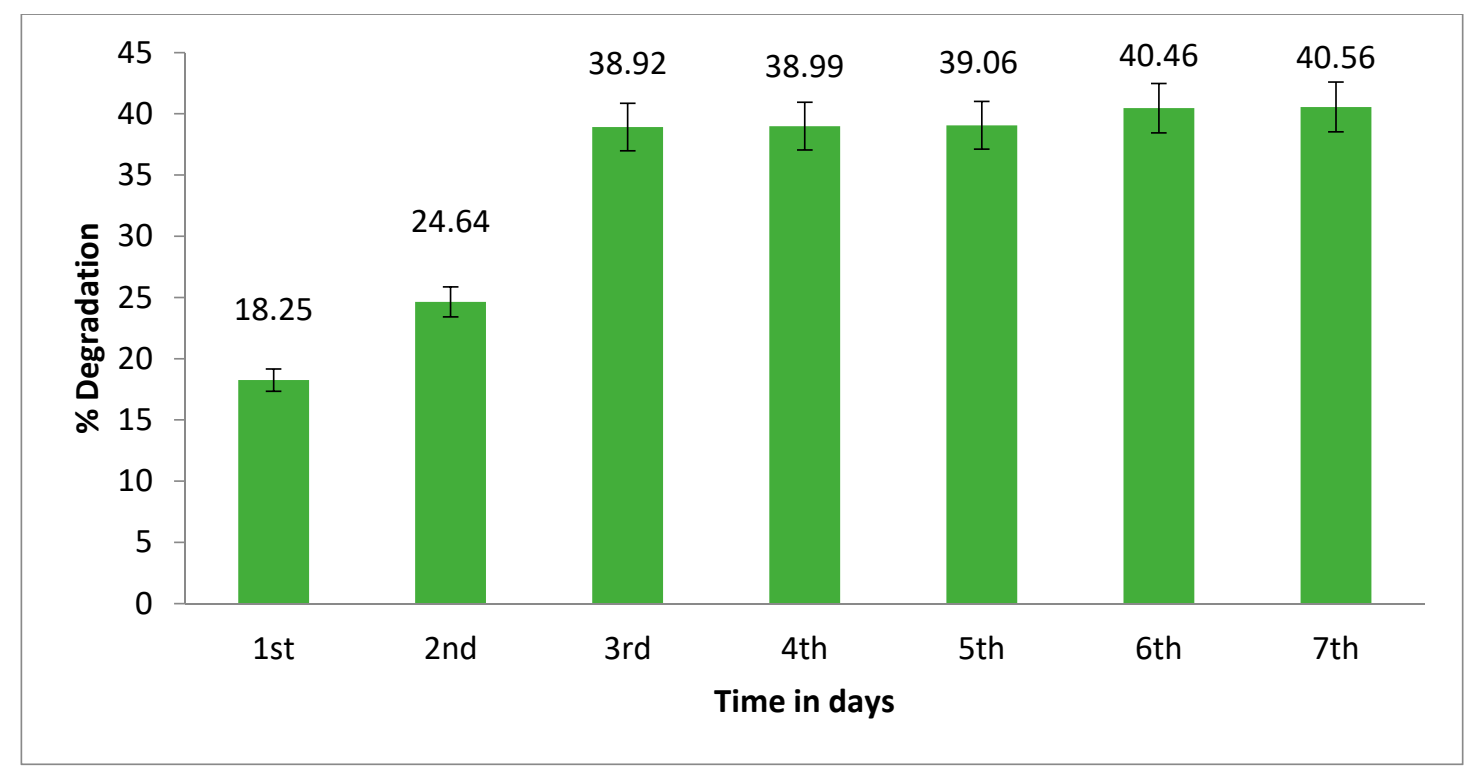

Figure 8. Effect of time in days on \% degradation of brown 706.

\subsection{Degradation of Brown 706 Dye at Optimum Physiochemical Conditions}

After determination of different physicochemical conditions such as dye concentration, $\mathrm{pH}$, temperature, sugar concentration, salt concentration and time on dyes degradation by selected bacteria. The synergestic effect was was high and $73.91 \%$ of degradation was observed under optimized conditions. 


\subsection{Fourier-Transform Infrared Analysis}

The FTIR spectra of undegraded dye is shown in Figure 9. A peak at $3435 \mathrm{~cm}^{-1}$ representing amine $\mathrm{N}-\mathrm{H}$ stretching. The peak at $1587 \mathrm{~cm}^{-1}$ corresponds to $\mathrm{N}=\mathrm{N}$ stretching; while a peak at $1483 \mathrm{~cm}^{-1}$, represents aromatic $C=C$ stretching. The peaks from 810 to $739 \mathrm{~cm}^{-1}$ represents benzene ring attached $\mathrm{N}-\mathrm{H}$ group whereas the peaks of $\mathrm{C}-\mathrm{H}$ stretching are ranged from 699 to $900 \mathrm{~cm}^{-1}$.

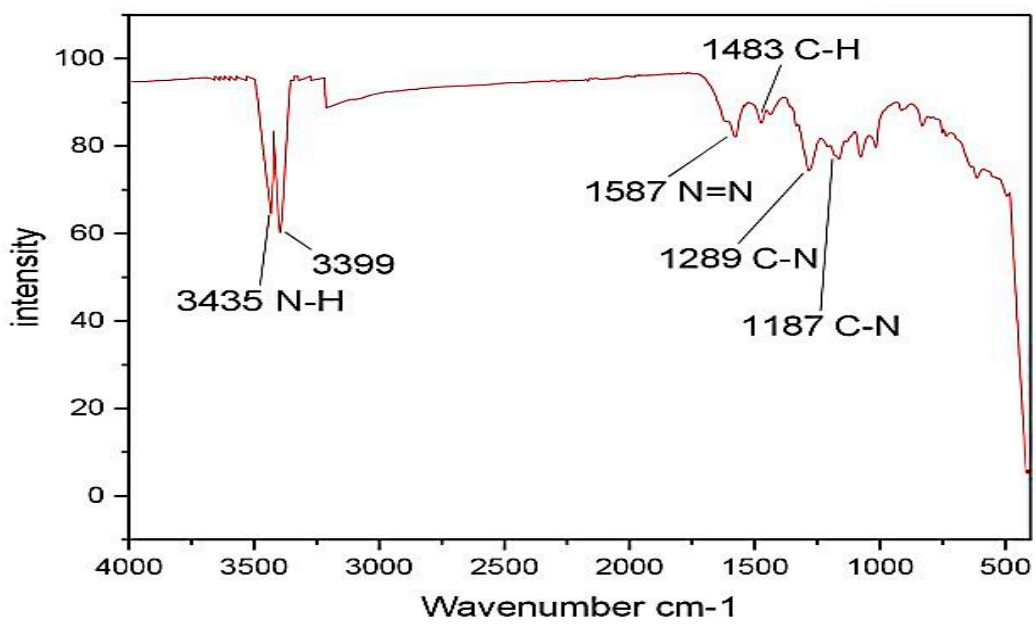

(a)

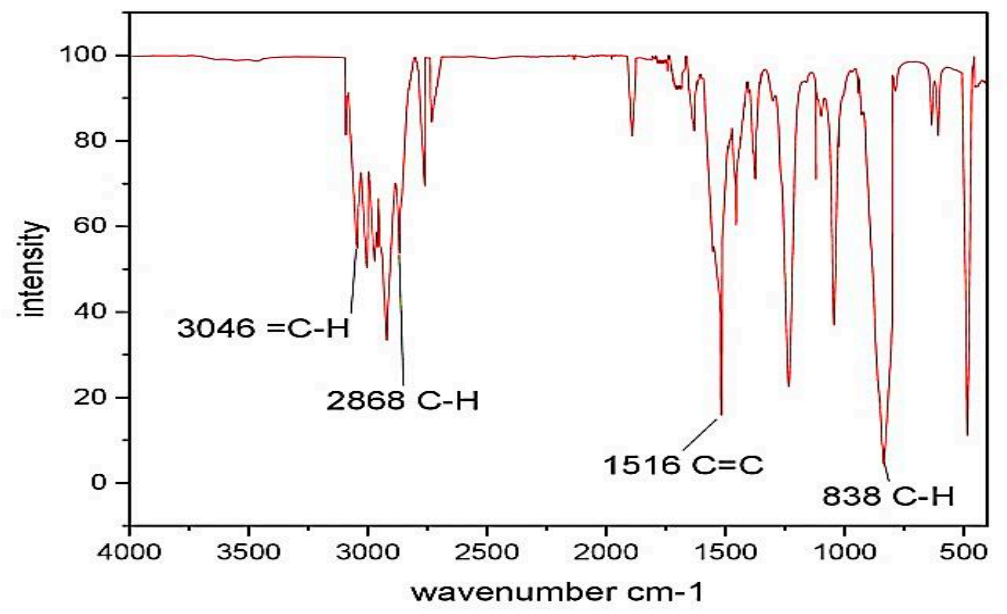

(b)

Figure 9. (a) Brown 706 Original dye FTIR. (b) Brown 706 dye FTIR after Pseudomonas aeruginosa Degradation.

Significant changes can be noted if the FTIR spectra of the original dye is compared with the metabolites spectra (Figure 9b). Some of the peaks have disappeared, whereas some new peaks have appeared, indicating the dye degradation. The disappearance of the peak at $1587 \mathrm{~cm}^{-1}$ indicates that the azo bond has been broken down as most of the bacterial strains contain azoreductases which breaks the azo bond. The peak at $3046 \mathrm{~cm}^{-1}$ represents $=\mathrm{C}-\mathrm{H}$ stretching on benzene ring, while the peak at $2868 \mathrm{~cm}^{-1}$ belongs to saturated C-H streching of the methyl group. The peak at $1516 \mathrm{~cm}^{-1}$ represents stretches of $\mathrm{C}-\mathrm{C}$ bond. Overall the two spectra are different from each other drastically and it is quite difficult to correlate them. However, the key finding is the disappearence of the azo bond peak which has been confirmed from NMR data of the degraded products as well. 


\subsection{Gas Chromatography and Mass Spectrometry}

The typical GC and GC-MS chromatograms of the metabolites are given Figure 10 whereas the important compounds identfied are given in Table 1. Most of the compounds that may probably be present are solvent based, as commercial grade solvents have been used. However, the compound detected at RT $2.20 \mathrm{~min}$ with a charge to ion mass equal to $106 \mathrm{~m} / \mathrm{z}$ relates to used dye structure and was identified as p-Xylene which has also been confirmed from carbon-13 and proton NMR as well.

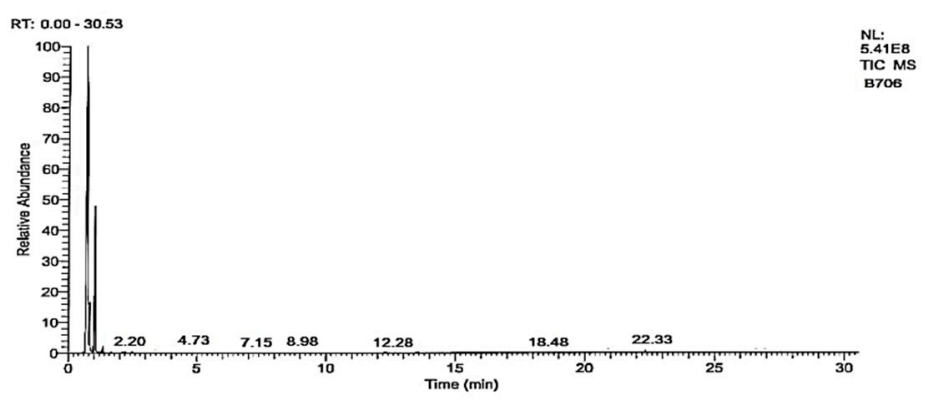

GC chromatogram of brown 706 dye after Pseudomonas aeruginosa degradation

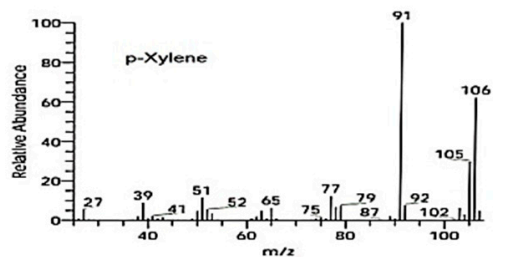

(a)

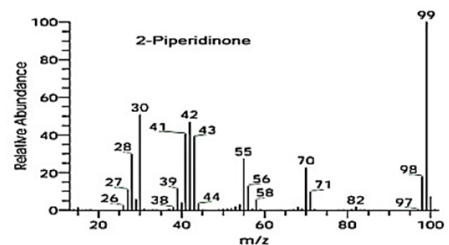

(c)

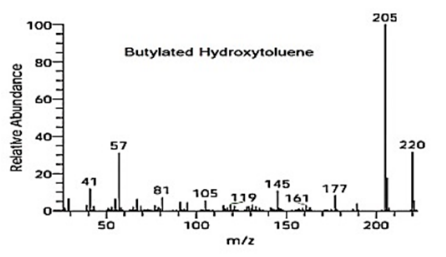

(e)

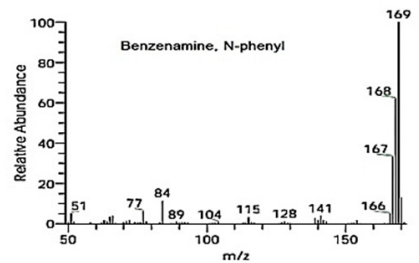

(g)

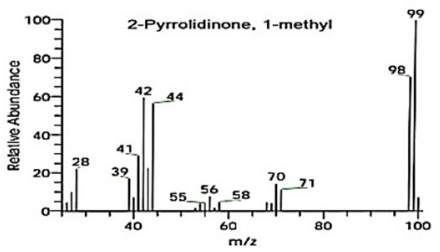

(b)

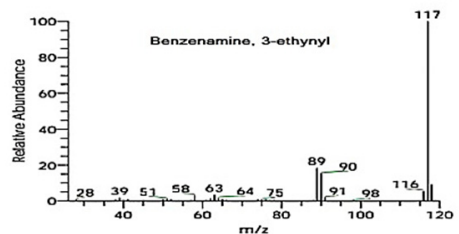

(d)

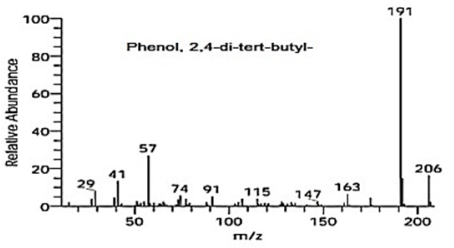

(f)

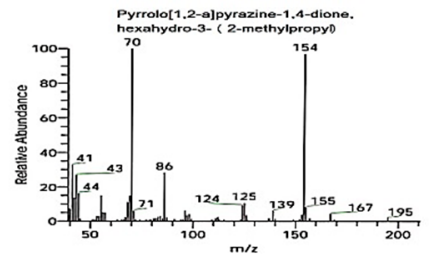

(h)

Figure 10. Cont. 


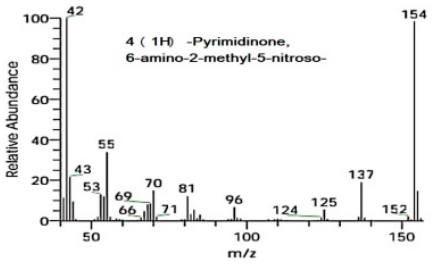

(i)

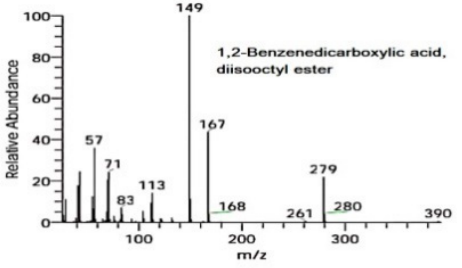

$(\mathrm{j})$

Figure 10. GC and GC-MS chromatograms of metabolites mixture.

Table 1. Identified compounds from degraded mixture through GC-MS analysis.

\begin{tabular}{|c|c|c|c|c|c|}
\hline S.NO & Compound Name & Retention Time & Peak Area & Chemical Formula & Molecular Weight \\
\hline 1 & p-Xylene & 2.20 & 0.45 & $\mathrm{C}_{8} \mathrm{H}_{10}$ & 106 \\
\hline 2 & 2-Pyrrolidinone, 1-methyl & 4.73 & 0.15 & $\mathrm{C}_{5} \mathrm{H}_{9} \mathrm{NO}$ & 99 \\
\hline 3 & 2-Piperidinone & 7.15 & 0.80 & $\mathrm{C}_{5} \mathrm{H}_{9} \mathrm{NO}$ & 99 \\
\hline 4 & Benzenamine, 3-ethynyl- & 8.98 & 0.08 & $\mathrm{C}_{8} \mathrm{H}_{7} \mathrm{~N}$ & 117 \\
\hline 5 & Butylated Hydroxytoluene & 12.28 & 0.17 & $\mathrm{C}_{15} \mathrm{H}_{24} \mathrm{O}$ & 220 \\
\hline 6 & Phenol, 2,4-di-tert-butyl- & 12.30 & 0.21 & $\mathrm{C}_{14} \mathrm{H}_{22} \mathrm{O}$ & 206 \\
\hline 7 & Benzenamine, N-phenyl & 13.91 & 0.17 & $\mathrm{C}_{12} \mathrm{H}_{11} \mathrm{~N}$ & 169 \\
\hline 8 & $\begin{array}{l}\text { Pyrrolo [1,2-a]pyrazine-1,4-dione, } \\
\text { hexahydro-3-(2-methylpropyl)- }\end{array}$ & 18.48 & 0.50 & $\mathrm{C}_{11} \mathrm{H}_{18} \mathrm{~N}_{2} \mathrm{O}_{2}$ & 210 \\
\hline 9 & $\begin{array}{l}\text { 4(1H)-Pyrimidinone, } \\
\text { 6-amino-2-methyl-5-nitroso- }\end{array}$ & 18.48 & 0.50 & $\mathrm{C}_{5} \mathrm{H}_{6} \mathrm{~N}_{4} \mathrm{O}_{2}$ & 154 \\
\hline 10 & $\begin{array}{l}\text { 1,2-Benzenedicarboxylic acid, } \\
\text { diisooctyl ester }\end{array}$ & 22.33 & 0.36 & $\mathrm{C}_{24} \mathrm{H}_{38} \mathrm{O}_{4}$ & 390 \\
\hline
\end{tabular}

\subsection{NMR Spectra of Brown 706 Dye}

When the 1H NMR spectra of the original dye, Brown 706, was compared to the metabolites produced through biodegradation by bacterial strain, there was a clear difference. The ${ }^{1} \mathrm{H}$ NMR and ${ }^{13} \mathrm{C}$ NMR results are shown in Figures 11 and 12, respectively. The original dye Brown 706 does not give any spectra because the original dye contains Fe (iron) ion, which has low sensitivity and covers a range of more than $9000 \mathrm{ppm}$ that is not possible to show in the spectra. After biodegradation of Brown 706 through the bacterial strain Pseudomonas aeruginosa, it passes through column chromatography to separate metabolites on the basis of size, which were then characterized through NMR. Out of the obtained metabolites only p-xylene was confirmed through NMR analysis which was further confirmed from its absorption peak at $260 \mathrm{~nm}$ of $\mathrm{UV}$-visible spectrum. The ${ }^{1} \mathrm{H}$ NMR spectra of P-Xylene are shown in Figure 13, whereas the ${ }^{13} \mathrm{C}$ NMR spectra are shown in Figure 14.

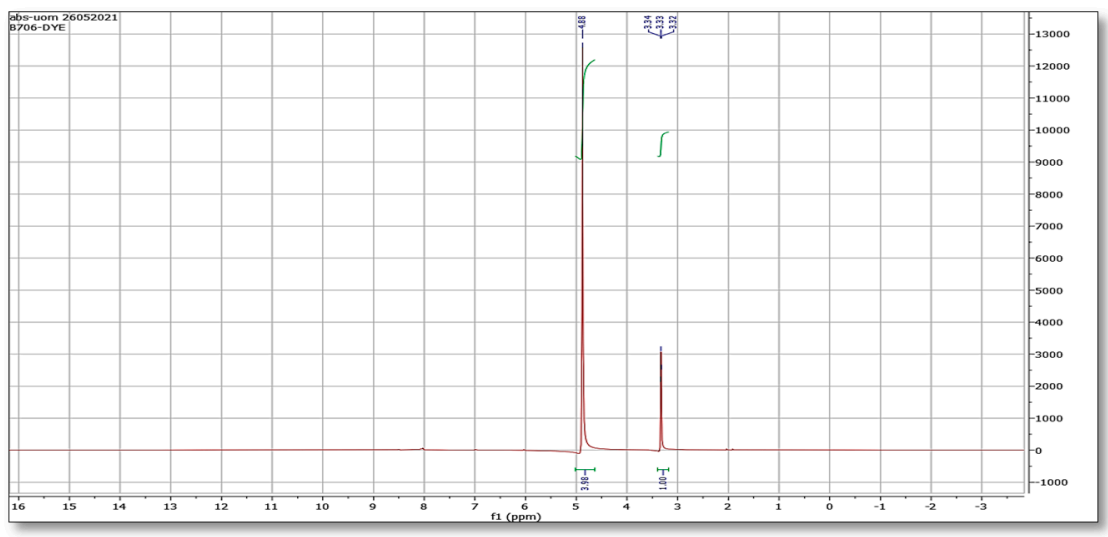

Figure 11. Original Dye Brown $706{ }^{1} \mathrm{H}$ NMR. 


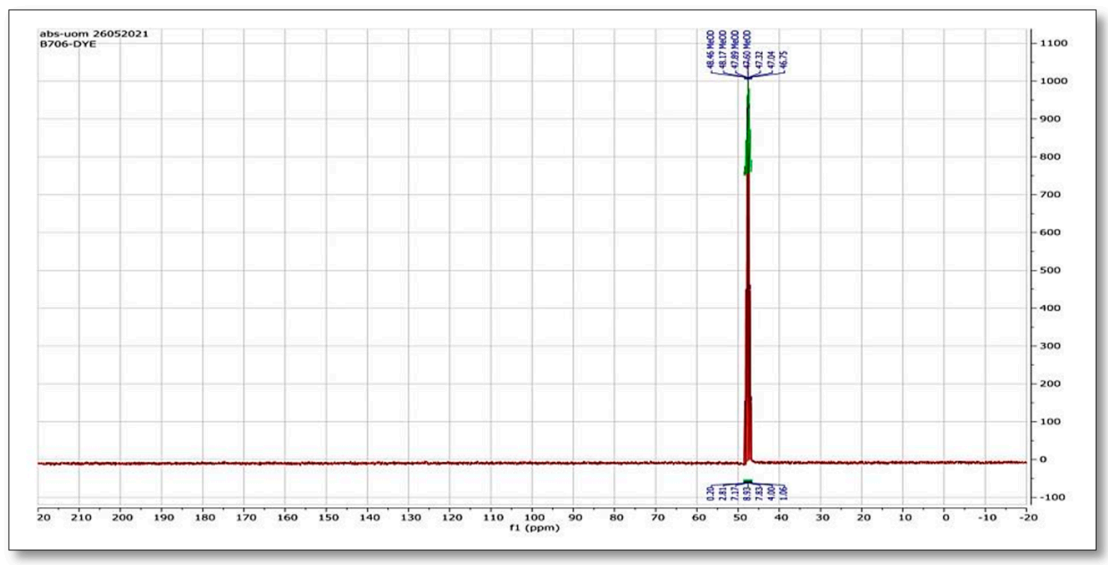

Figure 12. Original Dye Brown $706{ }^{13} \mathrm{C}$ NMR.

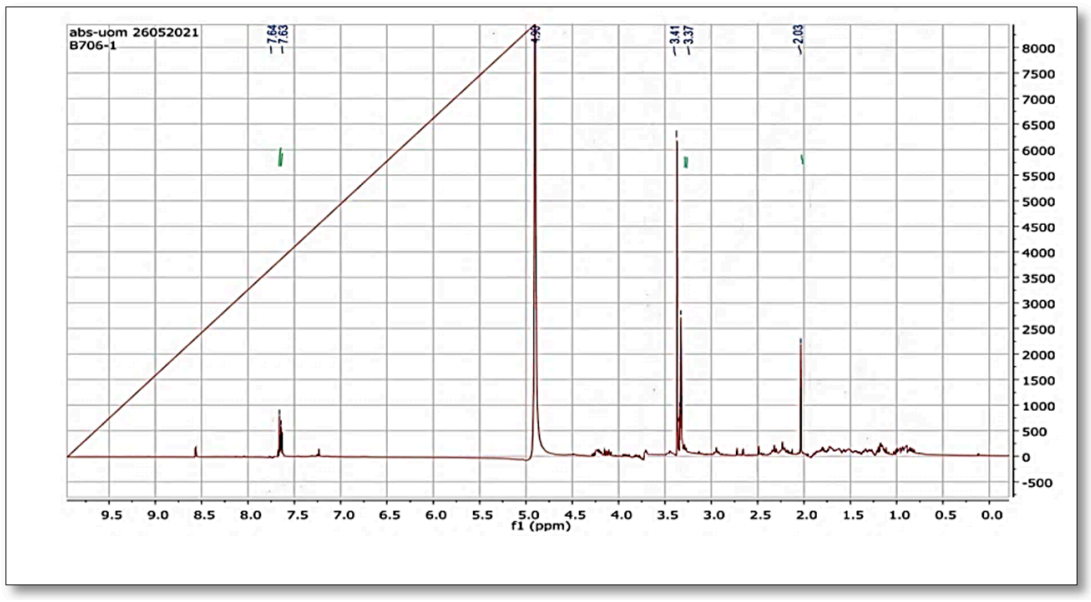

Figure 13. ${ }^{1} \mathrm{H}$ NMR after Pseudomonas aeruginosa degradation.

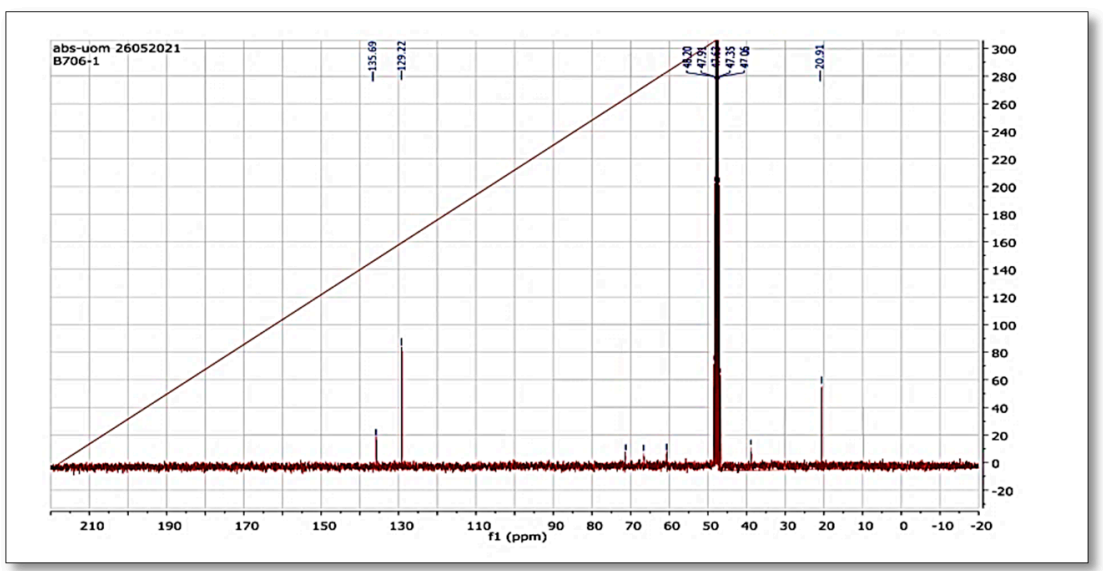

Figure 14. ${ }^{13} \mathrm{C}$ NMR after Pseudomonas aeruginosa degradation.

1H NMR: The peaks at $2.03 \delta \mathrm{ppm}$ was attributed to aliphatic- $\mathrm{CH}_{3}(3 \mathrm{H}, \mathrm{s})$ protons. The multiple peaks at 3.37, 3.41 and $4.90 \delta \mathrm{ppm}$ were assigned as methanol. The peak at $7.63 \delta \mathrm{ppm}$ and $7.64 \delta \mathrm{ppm}$ were attributed to aromatic protons.

${ }^{13} \mathrm{C}$ NMR of brown 706 showed two types of peaks aromatic carbon and aliphatic methyl carbon. The peaks of $129.22 \delta \mathrm{ppm}$ and $135.69 \delta \mathrm{ppm}$ were attributed to aromatic carbons. The peaks at $20.91 \delta \mathrm{ppm}$ were assigned as aliphatic methyl carbon. The peaks at $47.06,47.35,47.63,47.91$ and 48.20 were assigned as methanol carbons.

${ }^{1} \mathrm{H}$ NMR (300 MHz, methanol) for a J-value of (7.64 ppm-7.63 ppm) $\times 300 \mathrm{MHz}=3 \mathrm{~Hz}$. 


\subsection{Proposed Mechanism Reponsible for the Biodegradation}

Bacteria contains enzymess such as azoreductase, laccase, and peroxidase and thus are able to degrade azo dyes. The azoreductase enzyme split the $-\mathrm{N}=\mathrm{N}-$ bond and are thus, able to degrade azo dye under both anaerobic and aerobic conditions. Subsequently the two substituted benzene derivatives are formed. Out of the them the sulphonate substituted ring is resistant to degradation [25] under anaerobic conditions (our experiment has been performed under anaerobic conditions). The nitro and anino group substituted ring can easily be deaminated initially through conversion of amino group to nitro group and then both the nitro groups are substituted by methyl groups leading to the formation of xylene. The methyl donors $S$-adenosyl-methionine or methyl-tetrahydrofolate are already present in bacteria and have been reported to be resposible for the methylation of benzene ring [26]. Scheme 1 shows the proposed mechanism of Brown 706 degradation by Pseudomonas aeruginosa.

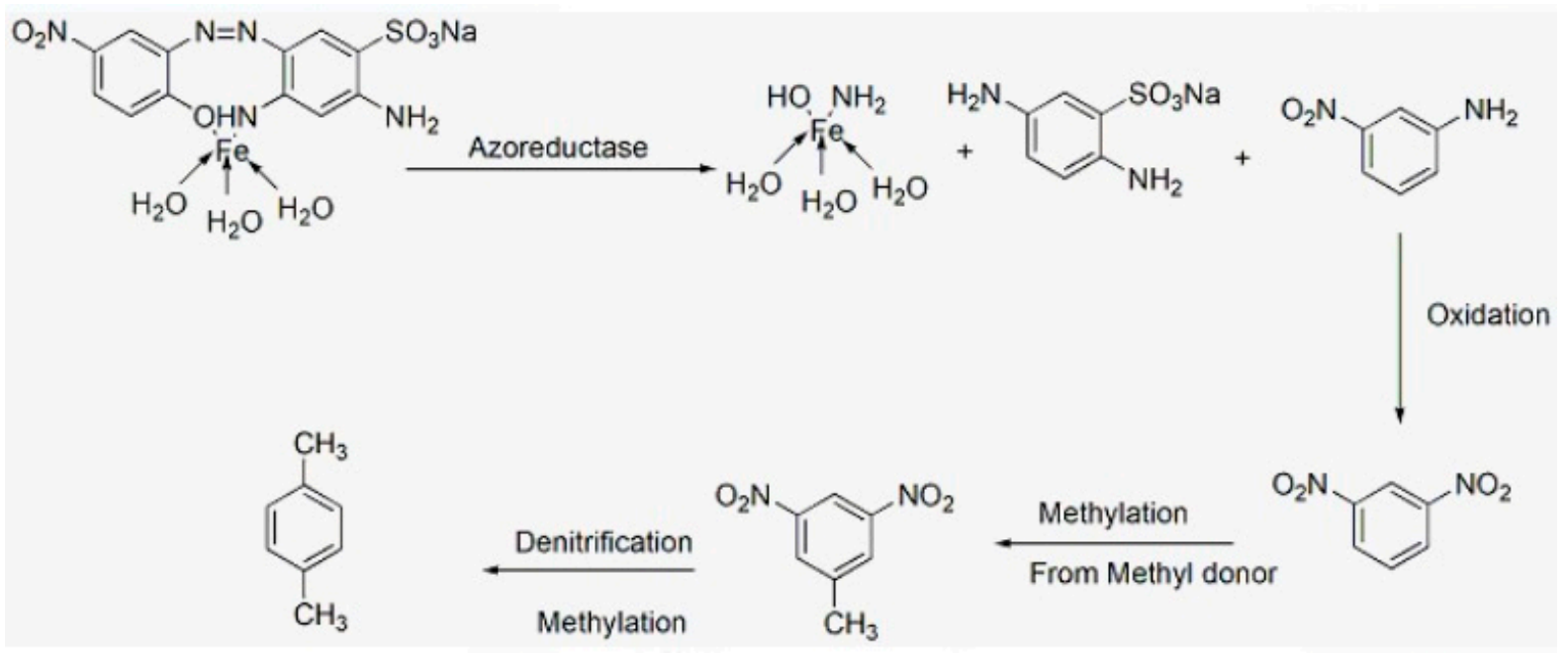

Scheme 1. Proposed mechanism of selected dye degradation by Pseudomonas aeruginosa.

\section{Conclusions}

In this study Brown 706 dye was subjected to bacterial degradation. Pseudomonas aeruginosa was the most efficient bacterial strain to degrade the selected dye. The effect of physicochemical parameters on degradation efficiency of bacteria were evaluated where 3 days time interval, $\mathrm{pH} 7,20 \mathrm{ppm}$ concentration $37^{\circ} \mathrm{C}$ of temperature, $0.5 \mathrm{~g}$ of glucose supplementation and $0.1 \mathrm{~g}$ of $\mathrm{NaCl}$ as tolerable salt concentration were found to be the optimum conditions. Finally all these optimum conditions were combined in a single experiment where $73.91 \%$ degradation of the selected dye was achieved. The metabolites were formed in last experimemt were extracted and characterized through GC-MS and FTIR spectroscopy. The metabolites were then separated through silica gel column and out of the obtained spectroscopic data only P-Xylene was confirmed through GC-MS and NMR analysis. The dye has been cleaved by azoreductase and subsequently deamination and methylation has led to the formation xylene.

Author Contributions: Conceptualization, A.U.K. and M.Z.; methodology, A.U.K., A.B.S. and M.Z.; software, A.U.K., A.B.S. and M.Z.; validation, A.U.K.; formal analysis, A.U.K. and I.Z.; investigation, I.Z.; resources, M.Z.; data curation; writing original draft preparation, M.U.R. and M.Z.; project administration. All authors have read and agreed to the published version of the manuscript.

Funding: This research received no external funding.

Institutional Review Board Statement: Not applicable.

Informed Consent Statement: Not applicable. 
Conflicts of Interest: The authors declare no conflict of interest. The funders had no role in the design of the study; in the collection, analyses or interpretation of data; in the writing of the manuscript or in the decision to publish the results.

\section{References}

1. Ikram, M.; Zahoor, M.; Khan, E.; Umar Khayam, S.M. Biodegradation of Novacron Turqueiose (Reactive Blue 21) by Pseudomonas aeruginosa. J. Chem. Soc. Pak. 2020, 42, 737-745.

2. Khayam, S.M.U.; Zahoor, M.; Khan, E.; Shah, M. Reduction of Keto Group in Drimarene Blue by Aspergillus Niger: A Predominant Reason for Subsequent Decolorization. Fresenius Environ. Bull. 2020, 29, 1397-1410.

3. Aisha, P.; Sayeda, S.Z. Effects of water pollution on human health: A review. World J. Pharm. Pharm. Sci. 2018, 7, 503-509.

4. John, L.C.L.; Andrew, L.A.; Stanislaus, T.V.L.; Moses, L.A. Investigation on the Impact of Water Pollution on Human Health in Juba County, Republic of South Sudan. J. Environ. Pollut. Hum. Health 2018, 6, 89-95.

5. Alam, S.; Khan, M.S.; Bibi, W.; Zekker, I.; Burlakovs, J.; Ghangrekar, M.M.; Bhowmick, G.D.; Kallistova, A.; Pimenov, N.; Zahoor, M. Preparation of activated carbon from the wood of Paulownia tomentosa as an efficient adsorbent for the removal of acid red 4 and methylene blue present in wastewater. Water 2021, 13, 1453. [CrossRef]

6. Andreea, M.D. Water Pollution and Water Quality Assessment of Major Transboundary Rivers from Banat (Romania). J. Chem. 2018, 2018, 9073763.

7. Sadoff, C.W.; Hall, J.W.; Grey, D.; Aerts, J.C.J.H.; Ait-Kadi, M.; Brown, C.; Cox, A.; Dadson, S.; Garrick, D.; Kelman, J.; et al. Securing Water, Sustaining Growth: Report of the GWP/OECD Task Force on Water Security and Sustainable Growth; University of Oxford: Oxford, UK, 2015; 180p.

8. Ikram, M.; Zahoor, M.; Batiha, G.E.S. Biodegradation and decolorization of textile dyes by bacterial strains: A biological approach for wastewater treatment. Z. Phys. Chem. 2020, 235, 1381-1393. [CrossRef]

9. Umar, A.; Khan, M.S.; Alam, S.; Zekker, I.; Burlakovs, J.; Bhowmick, G.D.; Kallistova, A.; Pimenov, N.; Zahoor, M. Synthesis and characterization of Pd-Ni bimetallic nanoparticles as efficient adsorbent for the removal of acid orange 8 present in wastewater. Water 2021, 13, 1095. [CrossRef]

10. Jabeen, S.; Sufaid Khan, M.; Khattak, R.; Zekker, I.; Burlakovs, J.; Ghangrekar, M.M.; Kallistova, A.; Pimenov, N.; Zahoor, M.; Khan, G.S. Palladium-Supported Zirconia-Based Catalytic Degradation of Rhodamine-B Dye from Wastewater. Water 2021, 13, 1522. [CrossRef]

11. Ong, S.A.; Ho, L.N.; Wong, Y.S. Comparative study on the biodegradation of mixed remazol dyes wastewater between integrated anaerobic/aerobic and aerobic sequencing batch reactors. Rend. Lincei 2017, 28, 497-501. [CrossRef]

12. Brüschweiler, B.J.; Merlot, C. Azo dyes in clothing textiles can be cleaved into a series of mutagenic aromatic amines which are not regulated yet. Regul. Toxicol. Pharmacol. 2017, 88, 214-226. [CrossRef]

13. Bhatia, D.; Sharma, N.R.; Singh, J.; Kanwar, R.S. Biological methods textile dye removal from wastewater: A review. Crit. Rev. Environ. Sci. Technol. 2017, 47, 1836-1876. [CrossRef]

14. Barathi, S.; Karthik, C.; Nadanasabapathi, S.; Padikasan, I.A. Biodegradation of textile dye Reactive Blue 160 by Bacillus firmus (Bacillaceae: Bacillales) and non-target toxicity screening of their degraded products. Toxicol. Rep. 2020, 7, 16-22. [CrossRef] [PubMed]

15. Veni, P.; Satish, C.P.; Tushar, J.; Diksha, S.; Saurabh, G.; Saurabh, K.; Mukesh, S. Biodegradation of toxic dyes: A comparative study of enzyme action in a microbial system. In Smart Bioremediation Technologies; Academic Press: Cambridge, MA, USA, 2019; pp. 255-287.

16. Alaya, V.; Kodi, R.K.; Ninganna, E.; Gowda, B.; Shivanna, M.B. Decolorization of Malachite green dye by Stenotrophomonas maltophilia a compost bacterium. Bull. Natl. Res. Cent. 2021, 45, 81. [CrossRef]

17. Saratale, R.G.; Saratale, G.D.; Chang, J.S.; Govindwar, S.P. Decolorization and biodegradation of reactive dyes and dye wastewater by a developed bacterial consortium. Biodegradation 2010, 21, 999-1015. [CrossRef]

18. Farhan, H.; Huma, F.; Faisal, M.; Tanvir, S.; Muhammad, S.; Muhammad, I.; Sumaira, R.; Hamid, M.; Sabir, H. Isolation and characterization of a lead $(\mathrm{Pb})$ tolerant Pseudomonas aeruginosa strain HF5 for decolorization of reactive red-120 and other azo dyes. Ann. Microbiol. 2018, 68, 943-952.

19. Sunar, N.M.; Mon, Z.K.; Rahim, N.A.; Leman, A.M.; Airish, N.A.M.; Khalid, A.; Ali, R.; Zaidi, E.; Azhar, A.T.S. Bioremediation of coractive blue dye by using Pseudomonas spp. isolated from the textile dye wastewater. IOP Conf. Ser. Earth Environ. Sci. 2018, 140, 012062. [CrossRef]

20. Pearce, C.I.; Lloyd, J.R.; Guthrie, J. TThe removal of colour from textile wastewater using whole bacterial cells: A review. Dyes Pigment. 2003, 58, 179-196. [CrossRef]

21. Sihag, S.; Pathak, H.; Jaroli, D.P. Factors affecting the rate of 381 biodegradation of polyaromatic hydrocarbons. Int. J. Pure Appl. Biosci. 2014, 2, 185-202.

22. Bheemaraddi, M.C.; Shivannavar, C.T.; Gaddad, S.M. Effect of carbon and nitrogen sources on biodegradation of textile azo dye Reactive Violet 5 by Pseudomonas aeruginosa GSM3. Sch. Acad. J. Biosci. 2014, 2, 285-289.

23. Kuhad, R.C.; Sood, N.; Tripathi, K.K.; Singh, A.; Ward, O.P. Developments in microbial methods for the treatment of dye effluents. Adv. Appl. Microbiol. 2004, 56, 185-213. [PubMed] 
24. Cui, D.; Li, G.; Zhao, M.; Han, S. Decolourization of azo dyes by a newly isolated Klebsiella sp. strain Y3, and effects of various factors on biodegradation. Biotechnol. Equip. 2014, 28, 478-486. [CrossRef]

25. Coates, J.D.; Chakraborty, R.; McInerney, M.J. Anaerobic benzene biodegradation-A new era. Res. Microbiol. 2002, 153, 621-628. [CrossRef]

26. Pandey, A.; Singh, P.; Iyengar, L. Bacterial decolorization and degradation of azo dyes. Int. Biodeterior. Biodegrad. 2007, 59, 73-84. [CrossRef] 